Vasile CHISELIŢĂ

\title{
DOCUMENTARY SOURCES AND METHODOLOGICAL LANDMARKS IN THE RESEARCH OF THE CREATION OF THE SINGER VERONICA MIHAI IN THE „FOLCLOR” ORCHESTRA
}

\author{
Rezumat \\ Surse documentare şi repere metodologice în cercetarea creaţiei interpretei \\ Veronica Mihai în orchestra „Folclor”
}

DOI: https://doi.org/10.52603/arta.2021.30-2.04

Studiul îşi propune să identifice criteriile teoretice şi metodologice de bază, importante în formarea viziunii ştiinţifice aplicate abordării creaţiei interpretative a cântăreţei populare profesioniste Veronica Mihai cu orchestra de studio „Folclor”, care a fost creată în anul 1967, în cadrul Companiei de stat de Televiziune şi Radiodifuziune din RSS Moldovenească. Autorul delimitează două perioade distincte în evoluţia repertoriului artistei: perioada tardivă sovietică (1968-1991) şi perioada post-sovietică (1991-1999). Atenţia principală se focusează pe epoca sovietică. Printre sursele documentare sunt materialele stocate în arhiva instituţiei, în special, dosarele personale ale artiştilor, procesele verbale ale Consiliului artistic, partiturile muzicale, cartoteca redacţiilor, interviurile cu artiştii, inclusiv materialele de presă, eseurile şi releveele la temă. Întru fundamentarea teoretică a studiului, se argumentează necesitatea instrumentalizării conceptelor de „cântec popular sovietic”, „cântec de mase”, „reţele de creaţie”, modernizare, revitalizare, tradiţii inventate, folclorizare, „cântec popular nou”, muzică neo-tradiţională.

Cuvintele-cheie: Veronica Mihai, repertoriu, tendinţe estetice, orchestra „Folclor”, muzică neo-tradiţională, Republica Moldova

\section{Summary \\ Documentary sources and methodological landmarks in the research of the creation of the singer Veronica Mihai in the „Folclor” Orchestra}

The study aims to identify the main theoretical and methodological criteria, important in shaping the scientific vision applied to the approach of the subject. The author delimits two distinct periods in the evolution of the singer's repertoire: the late Soviet period (1968-1991) and the post-Soviet period (1991-1999). The main focus is on the Soviet epoch. Among the documentary sources are the materials stored in the IPNA archive - "Teleradio-Moldova" Company, the personal files of the artists, the minutes of the Artistic Council, the musical scores, the library of the editorial offices within the institution. To substantiate the theoretical framework of the study, the author argues the need to instrumentalize the concepts of "Soviet folk song”, „mass song”, „creator\&producer networks”, „modernization”, „revitalization”, „invented traditions”, „folklorization”, „new folk songs”, „neo-traditional music".

Keywords: Veronica Mihai, singer repertoire, estetic tendencies, Folclor Orchestra, neo-traditional music, Republic of Moldova.

In this approach we will focus on identifying documentary landmarks and theoretical-methodological criteria, important in shaping the scientific vision applied to research of the innovative interpretive creation of singer Veronica Mihai with the professional folk music orchestra "Folclor", in the socio-political context and the aesthetic trends from the years 1960-1990. In a first stage, we do not pretend to inventory, analyze and synthesize the vast set of creations of the artist, which would require a much broader editorial development than the space offered by publishers. We limit ourselves to sketching some sursological aspects and categories, the stages of evolution of the institutionalized professional career, the principles of epistemological approach of the folklore heritage in the process of dynamic tension between the art of neo-traditional representation of cultural heritage and the political ideology of the time. 


\section{Arta muzicală}

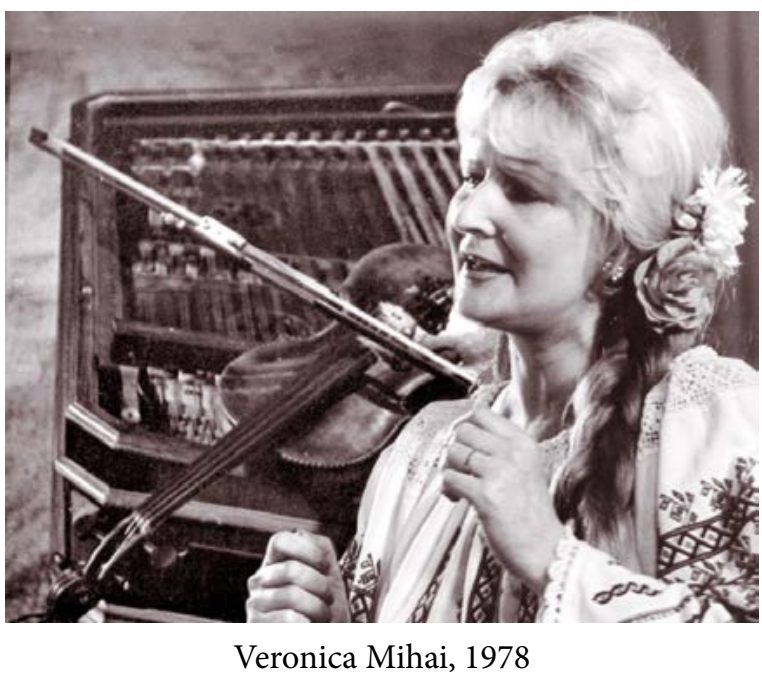

Veronica Mihai symbolizes the founding generation of the group of soloists-vocalists from the studio orchestra „Folclor”, created - according to archival documents (2) - in the last two months of 1967, within the Republican Television and Broadcasting Company (hereinafter - TRM), an institution then called the "State Committee of the Soviet of Ministers of the Moldovan SSR for Television and Broadcasting". Within this mainstream media and propaganda organization, Veronica Mihai was officially employed for almost 28 years, between 1968-1996 (1: 1995, file 64). Initially, she was accepted as a non-title artist (idem, file 5), she temporarily filling the position of assistant director of TV music shows, and from February 10,1970 , according to the extract from the order signed by Stepan Lozan, president of TRM (idem, f. 14), being transferred to the position of titular soloist of the orchestra in question, thus joining his fellow vocalists Ion Paulencu, Nina Ermurachi and Teodor Negară.

Further, we present some short biographical data, relevant for understanding the socio-cultural impulses and determinations in the evolution of the artist's professional career.

Veronica Mihai was born on July 17, 1945, in the village of Voroteţ, Orhei district, Moldavian SSR, in a family of needy peasants, who gave birth to two daughters. The older sister, Ludmila, was born in 1938. Her father, Lazăr (b. 1909), passed away prematurely (in 1956), little Veronica being raised by her "second" mother Raisa (b. 1930, the paternal name - Gladun), who was a simple field worker. The 8-year-old primary school student graduated from her hometown in 1961. As a pupil, Veronica often had to help her mother with the risky and toxic work on the kolkhoz's tobacco plantations. Beyond the sporadic opportunities of traditional enculturation within the local community, the first contact with the universe of popular music was, according to his own confessions (3), through radio waves. Thus, at the age of 8 , her mother bought a radio device „Rodina”, where she listens with great admiration to the folklore shows, broadcast by Radio Bucharest, thus being inspired by the repertoire of the most representative artists of Romanian national popular music of the time: Maria Tănase, Ioana Radu, Maria Lătăreţu, Benone Sinulescu and others. In the intention of looking for a purpose in life, at the suggestion of her mother, who could not support her materially, in 1961, Veronica comes to Chisinau, where two close relatives lived. First, she studies at the trade school no. 3 in the capital (1961-1963), following the activity as a crane and stainer at the construction trust „Kishiniovstroy”, later - as worker at the reinforced concrete factory no. 1 in the capital 1963-1968). Since 1966, she has been a soloist in the „Veselia” amateur ensemble, led by Dumitru Blajinu, with whom, in the year of the celebration by the Soviet state and the CPSU of the half-centenary of the socialist revolution 1967 - she became the winner of the Union Festival of Popular Creation in Moscow. He studies music and culturology and completes them in the form of non-attendance education, in two stages. First - supported by the renowned professor Loghin Ţurcanu - at the "Stefan Neaga” Republican School of Music in Chisinau (1966-1971), specialty „choral conducting”, with Irina Kalinova $(1$, file 4$)$, later - with the contest, the recommendation and the approaches of the TRM administration - at the "Gavriil Musicescu" State Institute of Arts from the capital (1980-1985), the specialty „cultural-educational work”, with Gheorghe Stepanov (1, file 24).

Since February 1968, at the invitation of conductor Dumitru Blajinu, she participates, as a non-titular trainee soloist, in the rehearsals and the first radio recordings of the new studio orchestra. In October 1968, by the decision of the TRM administration, he supported the competition to fill the vacancies of soloist-vocalist in the „Folclor” Orchestra, in which Larisa Arseni and Maria Sarabaş also participated. It is accepted, but on the condition of temporary employment in another position, that of second director of music shows, until the appearance of new vacancies. 
It should be noted that beyond the special artistic talent, the original vocal and timbre-expressive qualities of popular soprano with pronounced lyrical-dramatic nuances, the decision of the management and artistic council of TRM to be co-opted, namely in two stages, as artist of the new folk music „Folclor” Orchestra was significantly determined by the political context of the time, in particular, by the succession of major propaganda campaigns of totalitarian power in that period. Thus, we can observe that the first employment as a non-titular soloist of Veronica Mihai (1968) coincides with the stage of preparation for the lavish celebration of the 45th anniversary of the creation of the Moldovan SSR, considered to be the successor of RASSM. The musical symbol of the consecration of this political event in its own repertoire is marked by the recording in the audiovisual fund of the Company of the song in folk style, entitled: „Este-n floare ţara-ntreagă” (The whole country is in bloom), arrangement by Serghei Ciuhrii, author of lyrics strategically not indicated $(8,1969.27 .11$, p. 2). The second employment, this time as the soloist of the „Folclor" Orchestra (1970), is part of the campaign of preparation and grandeur celebration of the 100th anniversary of the birth of Vladimir I. Lenin, the founder of the Soviet state and Communist Power. It is known that in order to ensure such media campaigns of ideological mobilization of the masses, the decision-making bodies of the CPSU and the Government (Council of Ministers) allocated special financial resources to subordinate cultural institutions to be invested in supplementing staff, but also for completing the artistic repertoire with propagandistic, great and triumphant works "on the theme".

As a rule, such creations with alleged folk status, called "new folk songs", were insistently requested by all artists, conductors and creators by the Artistic Councils and literary newsrooms, which functioned, as evidenced by the numerous interviews we conducted with various musicians, as organs of censorship and control. The "Soviet folk songs", produced in the large network collaboration of educated musical and literary specialists, were required in order to folkloric legitimize of the hegemonic political power, but also to promote new norms, values and principles of social behavior. The creations in question were meant to enshrine the totalitarian ideology of government and the CPSU, appealing to the force of truth attributed to the voice of the entire "free and happy" people, to the incisive populism of the ideas of communist social justice, as propagandistic effects inculcated in the old Roman principle „vox populi”. The content of ideological songs „combines popular propaganda didactics with the moral-ethical sermons of eschatological socialism" (10, p. 8). The ideational, aesthetic and socio-functional framework of these pseudo-folk creations fits perfectly on the paradigmatic structure of the "Soviet mass song", constituting, in fact, as an autonomous stylistic subcategory within it. Consequently, quoting Elena Ganskaia, we can conclude that the new "popular” song symbolizes the "Soviet machine of meaning production”, "the ideal means of disseminating political doctrines", the process of aesthetic-ideological adherence of the local musical tradition to the arts "deeply optimistic and positivist", guided by the method of socialist realism, whose purpose was "not so much to reflect as to re-imagine reality" (11, pp. 211-212).

After the 1950s, in the repertoire of institutionalized, scenic, academized, concert folk orchestras, from the Moldavian SSR, the new model of Soviet folk-themed song became more and more important. This song has the task of sounding and disseminating in the general public "the myth of the great family of Soviet peoples" (11). Songs about the new life, socialist work, the ruling party, the leaders and official celebrations of the Soviet state, about the big and incomprehensible country, the country republic, the native republic, the unshakable friendship of the "sister republics", about selflessness, patriotic heroism, the ideals and ecstatic happiness of the toiling people etc., it is that phenomenon of folk art, which the historian and anthropologist Erik Horsbawn frames in the ritual practices of ,inventing traditions". Although „symbolic in nature”, newly invented traditions "seem or pretend to be old”, are „formally constituted or instituted". They are "governed by openly or tacitly accepted rules”, trying to „inculcate certain values and norms of (communist - our note) behavior". The invented traditions the author specifies more - are disseminated and intensely "generalized through the modern mass media of the radio" $(6$, p. 1$)$. To those mentioned, we can add the fact that the traditions invented by the "Soviet folk song" strongly favored the practices of "folklorizing" of the totalitarian doctrines in the consciousness of the large popular mass- 
es. Entering the system of folk genres, they had a number of adverse effects on historical tradition, often marginalizing, disrupting or blocking the promotion and continuity of old musical styles and categories.

The ideological songs "of socialism”, as the singer Veronica Mihai herself describes them in an interview (7), established, in fact, a new „way of transmitting tradition, knowledge and practices" (4, p. 95), which led to the change of the canon of traditional oral culture, to the creation of a new tradition in the realm of local folk music. In addition, folklorization provided monopolistic authoritarian power with „new means of claiming ethnic identity in the context of socialist economic development" $(5$, p. 69$)$. The phenomenon had lasting repercussions, especially on the collective mentality of Moldovans within the USSR. The presence in the repertoire of Moldovan Soviet folk songs, of great symbolic force, propagandistic and coercive, it is confirmed not only in the case of the protagonist of our study, but also in the case of the absolute majority of professional and amateur artists of the time.

During her work as a soloist-vocalist, which continued (as a non-holder) and after the dismissal assumed in 1995, at least until 1999, Veronica Minai managed - as it results from the General List of Works, elaborated by us - to register in the funds of the TRM institution and to capitalize in the media in the ether of the republican and union audio-visual a presumptive number, still indefinite, of about 170 vocal creations of neo-traditional music. They represent both a new species of music of inspiration and folk/popular imagination, a new form of reinvention, modernization, technological revitalization, media recontextualization and innovative orchestral capitalization of the ethnic and multicultural musical heritage of the past from Moldavia. At the same time, neo-traditional art is a creative platform for popularization, media coverage and wide social dissemination of new works written by authors in a ,intellectualized” and urbanized popular, socalled "folkloric" style.

Starting from these conceptual premises, we can advance the idea that neo-traditional creations from the repertoire of soloist Veronica Mihai tend to be located at the confluence of traditions and aesthetic-stylistic values of three distinct fields or genres of musical art: traditional art (oral), urban folk art (written-oral) and academic art of West- ern tradition (written).

Veronica Mihai's creative path covers two distinct historical periods: the late Soviet era within the USSR (1968-1991) and the first years of the post-Soviet era in the Republic of Moldova (1991-1999). The historical, political and ideological context of the reference periods left significant imprints on the aesthetic orientations, the specifics of the theme, the structure, the hierarchy of genera and species in the repertoire, on the style of interpretation of the creations. The stated ontological aspects can neither be neglected nor omitted, because they represent objective factors of the creation and production processes in the field. They raise before the researcher special theoretical and methodological problems, requiring a special attention and analytical exigency, focused on the instrumentalization of a modern vision with interdisciplinary character, promoted by both ethnomusicology and cultural anthropology and cultural studies.

In our previous approach we tried to identify and systematize the main available sources, the set of important and relevant documents on the topic. Among them are the materials stored in the IPNA Archive „Teleradio-Moldova” Company, in particular, the personal files of the artists, the minutes of the Artistic Council, the musical scores, the editorial library of the institution, which is joined by studies, essays and publications at theme, press articles, online audio and video sources, vintage photos, interviews with artists. Even if some of the journalistic narrative essays, especially those of a media nature, present various contradictory, unverified or even improvised, but the critical, comparative and corroborated analysis of all types of sources is able to provide a comprehensive, secure and multilateral framework of documentation for research. It promotes the creation of an overview of the object, which is able to outline the specific signs, clues and features of the innovative process of creation and production of neo-traditional musical art, in the context of the evolution of contemporary technological society in the late Soviet and post-Soviet period. Conceptualized, realized and promoted in the creative laboratory of the „Folclor” Orchestra, whose important and prodigious actor was the talented soprano Veronica Mihai, this art tends to represent the mark of the masterful ideological impact between the canonical tendencies and the traditionalist aesthetic aspirations of the collective, on the one hand, and 
the hegemonic policy of the state, projecting the values, needs and dynamic cultural preferences of the new Soviet public, which is in the process of urbanization, on the other.

At a first holistic look at Veronica Mihai's repertoire with the „Folclor” Orchestra it is necessary to observe the striking epistemological contradiction between the tendency of obsessive denomination of creations as "folkloric" or, in an analogous sense, „popular” musical instruments of the past, applied in the reference collective. Thus, from an interview on the theme of the soloist we find out that the conductor Dumitru Blajinu established as mandatory the task for each singer to collect folklore throughout the republic with a tape recorder. The soloists presented for their audition the materials gathered phonogramically and proposed to each other the desired or appropriate songs. A little further down, however, the protagonist reveals the real purpose and destination of those collected materials, namely: to be processed (sometimes substantially) in the form and the content, to be transformed, in particular, by readaptation and re-textualization.

Relevant in the description of some stages of the process of inventing the tradition, made on the platform of the new production and dissemination networks, are the following mentions of the artist, who quote: "We had to redo them, because in those collected from Grandma Anica the rhyme was not there and there! We had to do something with that song. Never (N.B.) have I sung the song just as I heard it! I left the tune of song, but the lyrics had to be done. The poets all helped us, because it was the Special Literary Council on the radio that helped us."

From the above, we can conclude that the folk materials collected phonogram by the soloists of the "Folklore” Ochestra served, rather, as a pretext, premise or impetus for the initiation and development of a new creative processes, the nature of which can only be categorized as "by inspiration”, „by imitation”, „by imagination” or „by folk resourcing”. In such creative processes, unknown to the oral tradition of the past, is involved a new and wide industrial network of creators, producers and professional mediators of culture, a phenomenon specific to the contemporary era, well known and studied in the special literature. In our case, there are, on the one hand, the educated musicians and writers, such as the conductors, composers, arrangers, collectors, singers, songwriters, poets and professional lyricists, and on the other - the artistic and literary councils, media institutions, recording studios, radio, television and film, music and literary show editors, including creative industry technicians, sound and image operators, etc. As a result, of the synthetic collaboration of the actors in the large frame of the new socialist creators \& producers network of the representational arts, in the cultural landscape of the post-war Moldovan society appeared and imposed a new type of folk-inspired popular creation, written especially for, and performed by institutionalized, standardized and westernized popular orchestras, most patronized and controlled by the party-state. This phenomenon represent that type of popular creation, which we have credited, like specialists in the West, with the term „neo-traditional music”.

The repertoire of the singer Veronica Mihai represents an eloquent example of neo-traditional creation in Soviet and Post-Soviet Moldova, which requires further in-depth study.

\section{Bibliographical referencies}

1. ArTRM: IPNA Archive of the „Teleradio-Moldova" Company. DPA (Personal files of employees), year 1995, volume M, files1-65.

2. Chiseliţă V. Dumitru Blajinu - întemeietorul orchestrei „Folclor”: unele file documentare / Dumitru Blajinu - the founder of the „Folklore" Orchestra: some documentary files. In: Studiul artelor şi culturologie: Istorie, teorie, practică, nr. 2 (37), (Chişinău) 2020, p. 178182.

3. Cunoaşte-i povestea interpretei Veronica Mihai. „Cântă-mi lăutare”, red. Lenuţa Gheorghiţă, Busuioc TV, 25 septembrie 2017. - https://www.youtube.com/watch?v=3eL0HldxBI4 (accessed: 14.04.2021)

4. Doja A. Evolution et folklorisation des traditions culturelles. In: East European Quarterly, XXXII, No. 1, March 1998, p. 95-126. - https:// www.researchgate.net/publication/32221378_ Evolution_et_folklorisation_des_traditions_ culturelles (accessed:15.02.2021)

5. Grillot C. L'impact de la folklorisation dans lexpression identitaire. La fête de Guzang chez les Miao du Xijiang. In: Ateliers, no. 24, 2001, p.69-86. - http://journals.openedition.org/ateliers/8743 (accessed:13.05.2021)

6. Hobsbawn E., Ranger T. (edited by). The 
Invention of Tradition. Cambridge University Press, 1983, reprinted 2000. 320 pag. https://psi424.cankaya.edu.tr/uploads/files/ Hobsbawm_and_Ranger_eds_The_Invention_of_Tradition.pdf (accessed: 28.04.2021)

7. Mihai Veronica si Nina Ermurachi. Emisiunea „Suflet de Artist”, red. Maria Stoianov, Vocea Basarabiei TV, 13 iunie 2016. - https:// www.youtube.com/watch? $\mathrm{v}=\mathrm{HclE} 5 \mathrm{hnSEP}$ $\mathrm{k} \& \mathrm{t}=171 \mathrm{~s}$ (accessed: 02.05.2021)

8. PV: Procesele verbale ale Consiliului Artistic al TRM/ Minutes of the Artistic Council of TRM). In: Archive of the IPNA „Teleradio-Moldova" Company.

9. Veronica Mihai, În prim plan cu Veronica Ghimp. Publica TV, 13 iunie 2016. - https:// www.youtube.com/watch?v=bLf4UCJONBc (accessed: 22.02.2021)

10. Богданов К. A. Vox populi. Фольклорные жанры советской культуры. Предисловие, или что фольклорного и советской культу- ре. В журн.: Новое литературное обозрение, 22 декабря, 2014. / Bogdanov K. A. Vox populi. Fol'klotnye zhanry sovetskoi kul'tury. Predislovie, ili chto fol'klornogo v sovetskoi kul'ture. In: Novoie literaturnoie obozrenie, 22 december, 2014. (accessed: 15.01.2021)

11. Ганская Е. Н. Советская массовая песня как форма идеологии. В : Litera, 2019, № 2, c. 251-261. / Ganskaia, E.N. Sovetskaia massovaia pesnea kak forma ideologii. In: $\mathrm{Li}$ tera, 2019, nr. 2, p. 251-261. (transliterated) - https://nbpublish.com/library_read_article. php?id=29760 (accessed: 05.05.2021)

12. Гюнтер Х. Поющая родина (Советская массовая песня как выражение архетипа матери). В журн.: Вопросы литературы , 1997, № 4. / Guenther H. Poiushchaia rodina (Sovetskaia massovaia pesnea kak vyrazhenie arkhetipa materi). In: Voprosy literatury, 1997, vol. 4. - $\quad$ http://magazines.russ.ru/voplit/1997/4/ gunter.html (accessed: 3.01.2021) 